\title{
УПРАВЛІННЯ ІНВЕСТИЦИЙНИМИ ПРОЕКТАМИ ПІДПРИЄМСТВ ЗАЛІЗНИЧНОГО ТРАНСПОРТУ, ЯКІ РЕАЛІЗУЮТЬСЯ НА ЗАСАДАХ ДЕРЖАВНО-ПРИВАТНОГО ПАРТНЕРСТВА
}

\author{
Гараєв М., здобувач (УкрДУЗТ)
}

\begin{abstract}
Розкрито зміст державно-приватного партнерства $i$ встановлено основні організаційно-правові форми його реалізачії на залізничному транспорті. 3'ясовано негативні $i$ позитивні передумови реалізачії проектів державного-приватного партнерства на підприємствах залізничної галузі. Надано характеристику прочесів управління за етапами життєвого ииклу інвестиційних проектів у сфері державноприватного партнерства. Визначено роль і зміст стратегічного контролінгу в системі управління держсавно-приватними проектами підприємств залізничного транспорту.
\end{abstract}

Ключові слова: інвестиційний проект, державно-приватне партнерство, управління, етапи управління, стратегічний контролінг, підприсмства залізничного транспорту.

\section{УПРАВЛЕНИЕ ИНВЕСТИЦИОННЫМИ ПРОЕКТАМИ ПРЕДПРИЯТИЙ ЖЕЛЕЗНОДОРОЖНОГО ТРАНСПОРТА, РЕАЛИЗУМЫХ В СФЕРЕ ГОСУДАРСТВЕННО-ЧАСТНОГО} ПАРТНЕРСТВА

Гараев М., соискатель (УкрГУЖТ)

Раскрыто сущность государственно-частного партнерства и установлено основные организачионно-правовые формы его реализачии на железнодорожном транспорте. Выяснены негативные и позитивные предпосылки реализачии проектов государственно-частного партнерства на предприятиях железнодорожной отрасли. Предоставлена характеристика процессов управления за этапами жизненного ицкла инвестиционных проектов в сфере государственно-частного партнерства. Определена роль и содержание стратегического контроллинга в системе управления государственно-частными проектами предприятий железнодорожного транспорта.

Ключевые слова: инвестиционный проект, государственно-частное партнерство, управление, этапы управления, стратегический контроллинг, предприятия железнодорожного транспорта.

\section{MANAGEMENT OF INVESTMENT PROJECTS OF ENTERPRISES OF RAILWAY TRANSPORT, WHICH ARE IMPLEMENTED ON A PUBLIC-PRIVATE PARTNERSHIP}

\section{Garayev M., applicant (USURT)}

The article is devoted to the problem of activation investment activity of the enterprises railway transport on the basis of implementation projects of public-private 
partnership (PPP). The content PPP is disclosed and the main organizational and legal forms of its implementation in railway transport are established. A key factor in ensuring the effectiveness of PPP investment projects implemented on railway transport is the quality of management processes. Typical stages of development of public-private partnership are clarified. It is concluded that at present the implementation of PPP projects in Ukraine is complicated by both insufficiently formed institutional environment and systemic problems that constrain the socio-economic development of the country. The negative and positive aspects forming prerequisites of implementation projects PPP at the enterprises of railway branch are revealed. features of the railway industry, which affect the characteristics of PPP projects in the railway sector. Among these specific features are the following: the scale and integration of projects; partially public funding; close cooperation; coordination of activities by JSC "Ukrzaliznytsia". It is taken into account that PPP project management processes in railway transport have a certain "life cycle", which includes such phases as initiation (concept), organization and preparation, implementation and completion. Monitoring and control the project is carried out at all stages of the life cycle. The characteristic of management processes on stages of life cycle investment projects in the sphere PPP is provided. The role and content of strategic controlling in the management system publicprivate projects at the enterprises railway transport are revealed. Directions of strategic controlling in the PPP project management system for the effective implementation of strategic potential is provided by correcting the strategic goals and priorities, the Concept and the strategic action program, including the correction of functional strategies and individual business processes.

Key words: investment project, public-private partnership, management, management stages, strategic control, railway transport enterprises.

Постановка проблеми і її зв'язок з науковими або практичними завданнями. Сучасні тенденції розвитку i соціально-економічна значимість залізничного транспорту України та його інфраструктури в розвитку економіки, особливо в умовах стагнації і уповільнення темпів економічного зростання, обумовлює необхідність використання нових інструментів інвестування. Вектор вирішення цієї проблеми спрямований на поле взаємодії держави i приватного бізнесу, що реалізується за допомогою інструментів державно-приватного партнерства (ДПП). Державно-приватне партнерство - одна 3 найбільш популярних у світі форм співпраці, основа успішності реалізації якої полягає в тому, що кожна зі сторін співпраці володіє певними компетенціями і перевагами, при кооперації яких формується i створюється синергетичний ефект. Реалізація проектів залізничного транспорту на основі державно-приватного партнерства є якісно новим етапом взаємодії держави і бізнесу, що дозволить подолати обмежені можливості держави та іiі суб'єктів щодо фінансування інвестиційних проектів розвитку залізничної галузі.

Світова практика показує, що найважливішим фактором успішного розвитку проектів державно-приватного партнерства $\epsilon$ релевантне управління проектом. Це обумовлює актуальність вивчення i удосконалення підходів до побудови системи управління інвестиційними проектами на підприємствах залізничного транспорту, що реалізуються на засадах ДПП.

Аналіз останніх досліджень i публікацій i виділення невирішених частин загальної проблеми. Дослідженню теоретичних і практичних засад державноприватного партнерства та їх реалізації в транспортному комплексі країни присвятили свої праці такі вчені, як Авксєнтьєв М.Ю. [1], Н.М. Бондар [2], Варнавський В.Г., Клименко А.В., 
Корольов В.А. [3], Вдовенко Ю.С. [4], В.А. Волохов, І.В. Маркова [5], Данько М.І., Дикань В.Л., Воловельська І.В. [6], Запатріна I.В. [7], Пащенко Ю.С., Корінь М.В. [8], I.В. Токмакова, О.О. Дараган [9] та інші. В наведених наукових публікаціях акцентується увага на організаційно-правові проблеми реалізації ДПП, перспективних формах ДПП на залізничному транспорті, механізмі забезпечення взаємодії партнерів. Разом 3 тим не приділяється достатня увага проблемам формування системи управління проектами державно-приватного партнерства на залізничному транспорті.

Мета статті полягає в розкритті змісту та специфіки управління інвестиційними проектами підприємств залізничного транспорту, що реалізуються на засадах державно-приватного партнерства.

Виклад основного матеріалу. Відсутність у світовій практиці загальновизнаного визначення ДПП, еталонної моделі і схеми управління проектами ДПП ускладнює завдання реалізації даного інвестиційного механізму.

В українському законодавстві [10] ДПП визначається, як співробітництво між державним та приватним партнерами, що здійснюється на договірній основі у рамках яких можуть укладатися договори про концесію, спільну діяльність, управління майном, змішаний договір, інші договори. Об'єктами державно-приватного партнерства $є$ об'єкти, що перебувають у державній або комунальній власності.

Як засвідчують вчені $[1,6,8]$ основні ознаки механізму ДПП, що обумовлюють його ефективність при залученні приватного бізнесу такі : 1) надання прав управління (користування, експлуатації) об'єктом партнерства або придбання, створення (будівництво, реконструкція, модернізація) об'єкта державно-приватного партнерства 3 подальшим управлінням (користуванням, експлуатацією), за умови прийняття та виконання приватним партнером інвестиційних зобов'язань відповідно до договору, укладеного в рамках державноприватного партнерства; 2) фіксація у договірних відносинах "державного інтересу"; 3) довгостроковість відносин (від 5 до 50 років); 4) передача приватному партнеру частини ризиків у процесі здійснення державно-приватного партнерства; 5) внесення приватним партнером інвестицій в об'єкти партнерства iз джерел, не заборонених законодавством.

Проекти ДПП можуть виконуватися в різних організаційно-правових формах. Дослідження аналітичних i наукових публікації [2-4, 7-8, 11] вказує, що найбільш поширеною формою ДПП на залізничному транспорті $є$ концесія, і останнім часом активно використовують такий іiі різновид як «контракт життєвого циклу», що заснований на алгоритмі «Проектування, будівництво, фінансування та експлуатація». Також в залізничній галузі застосовуються такі формі ДПП, як: поперше, контракти на управління та договори лізингу (оренди), що передбачають передачу приватному партнеру на певний період певних функцій 3 управління об'єктом інфраструктури, залишаючи за державою повноваження 3 прийняття інвестиційних рішень та несення операційних ризиків; по-друге, продаж (приватизація активів), за якої частина акцій транспортного об'єкту державної власності шляхом продажу (або шляхом приватизації) переходить у власність приватної компанії.

Досвід країн, які протягом довгого часу використовують ДПП для розвитку виробничої та соціальної інфраструктури, показує, що успіх і темпи просування ДПП залежать від ряду фундаментальних обставин, пов'язаних 3 ефективністю та якістю менеджменту. Потреба в безперервному виконанні безлічі бізнеспроцесів в рамках проекту ДПП, особливо тих, що носять унікальний характер, $\epsilon$ відправною точкою для застосування сучасних концепцій управління і проектноорієнтованого підходу. Останній 
передбачає розгляд окремо взятих завдань, що вирішуються в рамках реалізації проекту, як окремих підпроектів, до яких застосовуються принципи і методи проектного менеджменту. Застосування такого підходу в ДПП може стати основою для стандартизації управління даними проектами.

В Україні за даними центральних та місцевих органів виконавчої влади на 1 липня 2018 року укладено 192 договори ДПП, з яких реалізується 66 (41 договір концесії, 24 договори про спільну діяльність, 1 договір державно-приватного партнерства), 126 договорів не реалізується (4 договори - закінчено термін дії, 9 договорів - розірвано, 113 договорів - не виконується) [12]. Що вказує на першочергову необхідність удосоконалення системи управління ДПП.

Моделі управления ДПП не можуть бути створені без відповідного глибокого опрацювання. Кожна країна проходить через ряд етапів у побудові системи управління ДПП, перш ніж таке партнерство почне повноцінно функціонувати (табл. 1).

Етапи розвитку ДПП [13]

Таблиия 1

\begin{tabular}{|c|c|c|}
\hline Етап 1 & Етап 2 & Етап 3 \\
\hline $\begin{array}{l}\text { Формулювання основ } \\
\text { політики ДПП; } \\
\text { Перевірка правової } \\
\text { життєздатності; } \\
\text { Визначення } \\
\text { першочергових проектів; } \\
\text { Розробка базових понять; } \\
\text { Застосування досвіду } \\
\text { взаємодії держави з } \\
\text { іншими секторами } \\
\text { господарства; } \\
\text { Початок побудови ринку } \\
\text { послуг ДПП }\end{array}$ & $\begin{array}{l}\text { Формування } \\
\text { нормативно-правової } \\
\text { бази; } \\
\text { Підготовка } \\
\text { публікація практичних } \\
\text { посібників; } \\
\text { Утворення } \\
\text { ДПП; структур } \\
\text { Продовження розвитку } \\
\text { ринку послуг ДПП; } \\
\text { Розширення } \quad \text { низки } \\
\text { проектів з включенням } \\
\text { нових с секторів } \\
\text { господарства; } \\
\text { Залучення нових джерел } \\
\text { фінансових коштів }\end{array}$ & $\begin{array}{l}\text { Утворена працездатна система ДПП; } \\
\text { Ліквідовано правові бар'єри на шляху } \\
\text { розвитку ДПП; } \\
\text { Моделі ДПП вдосконалені; } \\
\text { Спостерігається потік укладених } \\
\text { контрактів ДПП; } \\
\text { Досягнутий } \\
\text { політичний консенсус; } \\
\text { Використовується повний спектр } \\
\text { джерел фінансування; } \\
\text { Розширюється спектр інвесторів в } \\
\text { інфраструкуру, включаючи пенсійні, } \\
\text { страхові та інші приватні фонди; } \\
\text { Досягнутий високий рівень знань } \\
\text { навичок у державних службовців, } \\
\text { здатних застосовувати досвід ДПП }\end{array}$ \\
\hline
\end{tabular}

Побудова системи управління ДПП потребує чіткого нормативно-правового регулювання i організаційного забезпечення взаємодії учасників інвестиційного проекту. Для цього в першу чергу необхідна відповідна підготовка представників державної влади, органів місцевого самоврядування і приватного капіталу, які будуть зайняті в реалізації спільного проекту. У цьому зв'язку показовим є досвід США, де до кожного проекту забезпечується індивідуальний підхід, оскільки такого роду проекти не мають шаблонного характеру. В кожному окремому випадку створюється консультаційний орган, що складається 3 представників державних структур та приватних компаній, а також проводиться навчання його учасників нормативно-правових i організаційноадміністративних особливостей реалізації проекту ДПП. Схожі міжгалузеві (міжвідомчі) групи 3 реалізації та контролю над розвитком проектів ДПП створені у Великобританії, Австралії, Португалії та Ірландії.

Нині реалізації проектів ДПП в Україні ускладнена як недостатньо сформованим середовищем, так і проблемами 
системного характеру, що стримують соціально-економічний розвиток країни.

Щодо базових умов реалізації проектів ДПП на залізничному транспорті України можна виділити як переваги, так i недоліки.

До позитивних факторів, що формують умови реалізації ДПП відносять: вигідне географічне положення на перетині міжнародних торгівельних коридорів, значний транзитний потенціал; кваліфікована робоча сила за найнижчою в Європі вартістю; фінансова та технічна підтримка з боку міжнародних організацій зі значним досвідом реалізації проектів ДПП у світі; нормативна база достатня для успішної реалізації проектів ДПП та іiі поступове удосконалення; наявність гнучкого механізму реалізації ДПП, що дозволяє розглядати різні моделі реалізації проектів, як 3 точки зору структури фінансування, так і з точки зору розподілу ризиків між партнерами у кожному окремому випадку; створення Проектного Офісу 3 реалізації проектів ДПП в інфраструктурі для підтримки та ефективної реалізації проектів ДПП; розробка методологічних та аналітичних матеріалів 3 реалізації проектів ДПП; участь міжнародних консультантів у реалізація пілотних проектів концесії у інфраструктурі та накопичення відповідного досвіду державними органами.

До факторів негативного впливу належать: швидка зміна державної політики та законодавчої бази, що ускладнює планування; військові дії на території країни, нестабільна політична ситуація, санкції з боку Росії, падіння транзиту; нестабільна економічна ситуація, високий рівень інфляції та низька купівельна спроможність населення; складність ведення бізнесу, низький рейтинг Doing Business; необхідність значних інвестицій у модернізацію інфраструктури та відсутність ресурсів у державному бюджеті; низька операційна ефективність наявної інфраструктури; недосконалість механізму реалізації проектів та оцінки їх ефективності, відсутність досвіду та кваліфікованих спеціалістів у реалізації ДПП; відсутність стратегії розвитку інфраструктури та визначення пріоритетів для реалізації проектів ДПП; декілька різних процедур реалізації проектів ДПП та відсутність чітких критеріїв їх застосування, протиріччя у законодавчій базі; відсутність довгострокового бюджетного планування та можливості встановлення «плати за доступність»; неефективна взаємодія між державними та місцевими органами влади, складна процедура погодження проектів через Кабінет міністрів України; незавершена реформа, що передбачає розділення інфраструктури та транспортних послу; відсутність механізму участі приватного партнера у побудові залізничної інфраструктури; заборона на концесію магістральних колій; відсутність конкуренції на ринку залізничних перевезень; збитковість пасажирських перевезень та перехресне субсидування їх за рахунок вантажних; невідповідність розвитку мережі прикордонних пунктів та логістичних центрів умовам зростання обсягів торгівлі; бюрократичність процедур оформлення вантажів при міжнародних перевезеннях.

Особливості залізничного господарства впливають на характеристики, які можуть бути притаманні проектам ДПП у залізничній сфері. Серед таких специфічних рис варто відзначити наступні: масштабність й інтегрованість проектів; частково державне фінансування; тісна співпраця; координація діяльності 3 боку АT «Укрзалізниця». Враховуючи зазначені особливості, варіантом структурування проекту ДПП на залізничному транспорті може бути створення управляючої компанії - окремої юридичної особи, яка перебуватиме у спільній власності приватного та державного партнерів, в результаті чого враховуватиме позиції 
обох засновників. Загалом, створення такої управляючої компанії в міжнародній практиці вважається одним 3 кращих варіантів управління проектами ДПП, який забезпечує баланс функцій та відповідальності приватного і державного партнерів. Однак в наших реаліях такий механізм наразі $€$ неефективним. Насамперед, володіння державним партнером істотною часткою в такій компанії може мати негативний вплив на ii повноваження розпоряджатися своїм майном та активами (наприклад, передача в оренду), а також покладатиме на управляючу компанію додаткові обов'язки та процедури (наприклад, державні закупівлі), які невластиві приватним компаніям. Золотою серединою може бути, наприклад, створення за договором ДПП окремого органу (комітету або комісії), в який входитимуть представники обох партнерів та повноваження якого включатимуть вирішення питань діяльності управляючої компанії. Проте відповідно до законодавства України, повноваження такого органу є достатньо суперечливим питанням, адже він не $є$ органом управління юридичної особи та представником засновників 3 повноваженнями впливати на рішення управляючої компанії. Водночас вирішення цього питання i зменшення ризиків хоча б частково може бути здійснене шляхом якісного структурування та детального опрацювання проекту договору ДПП (зокрема, положень про такий орган).

У процесі реалізації проектів ДПП в залізничній сфері виникатимуть також інші концептуальні питання (в тому числі щодо тарифного регулювання, забезпечення інтенсивності руху потягів, великого пасажиропотоку

вантажопотоку), які безпосередньо впливатимуть на проект i його прибутковість. Багато таких питань можна вирішити шляхом переговорів, пошуку найбільш оптимального розподілу ризиків та належного структурування проекту, як у прикладі з управляючою компанією.

В процесі управління проектами ДПП на залізничному транспорті слід враховувати, що вони мають певний «життєвий цикл», який включає такі фази як ініціація (концепція), організація та підготовка, реалізація та завершення. На всіх етапах життєвого циклу здійснюється моніторинг i контроль проекту. Кожна фаза повинна мати певні «входи» i «виходи», а також «віхи» проекту. При цьому проекти ДПП можуть бути ініційовані або державним або приватним партнером. Характеристика процесів управління проектами в сфері ДПП 3 позицій держави i приватного партнера представлена в таблиці 2.

При реалізації управління проектом ДПП необхідно орієнтуватися на кінцеві показники ефективності i результативності проекту, що досягаються на всьому інтервалі його життєвого циклу. Це забезпечується шляхом введення в систему управління проектом сукупності зворотних зв'язків, наприклад, 3 допомогою використання механізму стратегічного контролінгу. У системі управління проектом ДПП він являє собою комплексну систему підтримки стратегії проектного управління 3 метою контролю результативності та ефективності реалізації сукупності функціональних стратегій і протікають в їх рамках бізнес-процесів.

У процесі управління проектом ДПП конролінг охоплює: моніторинг стратегічних показників (показників) реалізації проекту; оцінку цих індикаторів (показників) шляхом порівняння 3 цільовими змінами; виявлення відхилень (які можуть мати як допустимий, так i критичний характер) фактичних значень показників від цільових індикаторів; розробку заходів 3 корекції стратегії проектного управління. 
Характеристика прочесів управління проектами у сфері ДПП

Таблиия 2

(сформовано на онові [14])

\begin{tabular}{|c|c|}
\hline Процеси управління ДПП-проектом з боку держави & $\begin{array}{c}\text { Процеси управління ДПП-проектом з боку } \\
\text { бізнесу } \\
\end{array}$ \\
\hline 1 & 2 \\
\hline $\begin{array}{l}\text { Ініціація проекту: } \\
-\quad \text { ідентифікація проекту; } \\
\text { - первинний аналіз показників проекту та оцінка його } \\
\text { ефективності (розробка концепції проекту); } \\
-\quad \text { експертиза концепцї проекту; } \\
-\quad \text { перевірка на предмет реалізованості в рамках ДПП; } \\
-\quad \text { рішення про підготовку проекту }\end{array}$ & $\begin{array}{l}\text { Iніціація проекту: } \\
-\quad \text { розроблення концепції проекту: } \\
-\quad \text { ідентифікація проекту, } \\
-\quad \text { первинний аналіз показників і } \\
\text { розрахунок ефективності проекту, } \\
-\quad \text { попередній розподіл ризиків та ін.; } \\
-\quad \text { подача заявки } \\
\end{array}$ \\
\hline $\begin{array}{l}\text { Підготовка (комплексна оиінка, структуризація та } \\
\text { експертиза) проекту та конкурсної документації: } \\
\text { - комплексна оцінка документації за проектами дПП, } \\
\text { запропонованими приватними компаніями; } \\
\text { - розроблення та затвердження повної документації за } \\
\text { проектом ДПП; } \\
\text { - вибір правової моделі реалізації дПП-проекту і форми } \\
\text { угоди з урахуванням інтересів всіх стейкхолдерів; } \\
\text { - оцінка та розподіл ризиків (побудова матриці ризиків); } \\
\text { - вибір фінансової моделі: джерел, механізму } \\
\text { фінансування і розподілу доходів, а також виду державної } \\
\text { підтримки ДПП; } \\
\text { - незалежна експертиза проекту; } \\
\text { - підготовка конкурсної документації }\end{array}$ & $\begin{array}{l}\text { Підготовка (комплексна оиінка та } \\
\text { обтрунтування) проекту та конкурсної } \\
\text { документації: } \\
\text { - розроблення і затвердження повного } \\
\text { пакету документації по проекту (паспорта } \\
\text { проекту, ТЕО, плану управління проектом } \\
\text { та ін.); } \\
\text { - оцінювання та розподіл ризиків } \\
\text { (побудова матриці ризиків); } \\
\text { - підготовка конкурсної документації }\end{array}$ \\
\hline $\begin{array}{l}\text { Управління конкурсом і управління контрактом: } \\
-\quad \text { затвердження конкурсної документації, } \\
-\quad \text { оголошення конкурсу, } \\
-\quad \text { прийом, попередній відбір заявок та повідомлення про } \\
\text { результати відбору, } \\
-\quad \text { прийом, розгляд та оцінка конкурсних пропозицій, } \\
-\quad \text { визначення переможця конкурсу; } \\
-\quad \text { проведення переговорів з переможцем; } \\
-\quad \text { укладення угоди про ДПП; } \\
-\quad \text { організація проектного фінансування та фінансове } \\
\text { закриття проекту; }\end{array}$ & $\begin{array}{l}\text { Участь у конкурсній процедурі та } \\
\text { управління реалізацією проекту: } \\
\text { - процеси участі в конкурсному відборі: } \\
\text { - подача заявки, } \\
\text { - подача конкурсних пропозицій; } \\
\text { - укладення угоди про ДПП; } \\
\text { - управління реалізацією проекту: } \\
\text { - координація людей і ресурсів, } \\
\text { - управління очікуваннями зацікавлених } \\
\text { сторін, } \\
\text { - інтеграція та виконання операцій } \\
\text { проекту відповідно до плану }\end{array}$ \\
\hline $\begin{array}{l}\text { Моніторинг та контроль виконання зобов'язань за угодою } \\
\text { ДПП: } \\
\text { - моніторинг виконання Угоди про ДПП та планових } \\
\text { показників проекту; } \\
-\quad \square \text { моніторинг ефективності використання бюджетних } \\
\text { коштів; } \\
-\quad \text { моніторинг ризиків і зобов'язань за проектом; } \\
-\quad \text { моніторинг якості послуг об'єкта угоди; } \\
-\quad \text { робота зі змінами за проектом; } \\
-\quad \text { контроль проектування, будівництва, введення в } \\
\text { експлуатацію та експлуатації об'єкта угоди }\end{array}$ & $\begin{array}{l}\text { Моніторинг та контроль реалізації } \\
\text { проекту: } \\
\text { - моніторинг виконання планових } \\
\text { показників та результатів реалізації } \\
\text { проекту; } \\
\text { - моніторинг ризиків проекту; контроль } \\
\text { проектування, будівництва, введення в } \\
\text { експлуатацію та експлуатації об'єкта } \\
\text { угоди; } \\
\text { - робота зі змінами за проектом }\end{array}$ \\
\hline $\begin{array}{l}\text { Закриття проекту: } \\
\text { - закриття проекту; } \\
\text { - закриття контракту; }\end{array}$ & $\begin{array}{l}\text { Закриття проекту: } \\
\text { - закриття проекту; } \\
\text { - закриття контракту; } \\
\text { - архівація всіх значущих документів } \\
\text { проекту в інформаційній системі } \\
\text { управління проектами; } \\
\text { - оцінювання всіх членів команди та } \\
\text { вивільнення ресурсів проекту тощо. }\end{array}$ \\
\hline
\end{tabular}


Загалом стратегічний контролінг проектів ДПП спрямований на ефективну реалізацію стратегічного потенціалу проекту ДПП, що забезпечується шляхом корекції стратегічних цілей і пріоритетів, Концепції і стратегічної програми дій, включаючи корекцію функціональних стратегій i окремих бізнес-процесів. У зв'язку з цим при проектуванні системи управління проектом ДПП значиму роль починають відігравати такі аспекти, як вибір ключових індикаторів i їх критеріальних (еталонних) значень, формування підсистем контролю проектних ризиків, стратегічного, тактичного i оперативного планування, менеджменту якості та ряду інших. Крім того, функціонування системи управління ДПП проектом неможливе без ефективного інформаційного

забезпечення.

Висновок. Таким чином, ефективність інвестиційних проектів залізничного транспорту, які реалізуються на засадах ДПП залежить від якості управління, що потребує удосконалення управлінського інструментарію на державному рівні та на рівні підприємств залізничного транспорту i приватних інвесторів. Організаційний контекст підвищення результативності управління проектами ДПП залізничного транспорту відбувається шляхом створення спеціального координаційного органу, що забезпечить подальшу співпрацю між партнерами проект, яка необхідна на всіх етапах життєвого циклу проекту.

\section{ПЕРЕЛІК ВИКОРИСТАНИХ ДЖЕРЕЛ}

1 Авксєнтьєв М.Ю. Державноприватне партнерство як сучасний механізм залучення інвестицій в інфраструктурні галузі України: автореферат дис. на здоб. наук. ступеня к.е.н.; за спеціальністю 08.00.03 «Економіка та управління національним господарством» / М.Ю. Авксєнтьєв. - Київ: Науково-дослідний економічний інститут, 2010. - 22 с.
2 Бондар Н.M. Розвиток транспортної інфраструктури України на засадах державно-приватного партнерства: монографія / Н.М. Бондар. - К.: НТУ, 2014. $-336 \mathrm{c}$.

3 Варнавский В. Г. Государственно-частное партнерство: теория и практика / В.Г. Варнавский, А.В. Клименко, В.А. Королев. - М.: ГУ-ВШЭ, 2010. - 287 c.

4 Вдовенко Ю.С. Приватнодержавне партнерство в автодорожній сфері: монографія / Ю.С. Вдовенко. Чернігів: ЧДТУ, 2009. - 198 с.

5 Волохов В.А. Обгрунтування впровадження механізму державноприватного партнерства на залізничному транспорті / В.А. Волохов, І.В. Маркова // Вісник економіки транспорту i промисловості. - 2010. - № 32. - С. 25-28

6 Запатріна I. В. Публічноприватне партнерство в Україні: перспективи застосування для реалізації інфраструктурних проектів i надання публічних послуг / I. В. Запатріна // Економіка і прогнозування. - 2010. - № 4. C. 62-86.

7 Данько М.I. Вибір оптимальної інноваційної стратегії підприємств залізничного транспорту: монографія / М.I. Данько, В.Л. Дикань, I.В. Воловельська. - Харків: УкрДАЗТ, 2013. $205 \mathrm{c}$.

8 Пащенко Ю.Є. Державноприватне партнерство як механізм фінансового забезпечення розвитку транспортної інфраструктури залізниць / Ю. Є. Пащенко, М. В. Корінь // Вісник економіки транспорту і промисловості. 2015. - Вип. 49. - С. 74-79.

9 Токмакова I. В. Сутність та підходи до формування інвестиційної стратегіï на підприємствах залізничного транспорту / І.В. Токмакова, О.О. Дараган // Вісник економіки транспорту i промисловості. - 2013. - Вип. 43. C. 189-193.

10 Про державно-приватне партнерство: Закон України від 1 липня 
2010 року № 2404-VI [Електронний pecypc]. - Режим доступу: http://zakon2.rada.gov.ua/laws/show/2404-17.

- Назва з екрана.

11 Реалізація проектів державноприватного партнерства в Україні: практичний посібник [Електронний pecypc]. - Режим доступу: https://mtu.gov.ua/files/Посібник\%20Реаліза ція\%20ДПП\%20в\%20Україні.pdf. - Назва 3 екрана.

12 Довідка щодо результатів здійснення ДПП (1 півріччя 2018 рік) Електронний ресурс]. - Режим доступу: http://www.me.gov.ua/Documents/Print?lang= uk-UA\&id=62a9b6fb-27ff-462a-b351-

eeeadfb26b6f - Назва з екрана.

13 Морозова Н.И. Роль государственно-частного партнерства в формировании и реализации социально ориентированной политики России / Н.И. Морозова // Європейські перспективи. 2013. - № 6. - С. 5-12.

14 Государственно-частное

партнерство : учеб. пособие для бакалавриата и магистратуры / под ред. И. Н. Ткаченко. - М. : Издательство Юрайт, 2016. - $188 \mathrm{c}$.

\section{REFERENCES}

\section{Avksjentjjev M.Ju.}

(2010)

Derzhavno-pryvatne partnerstvo jak suchasnyj mekhanizm zaluchennja investycij $v$ infrastrukturni ghaluzi Ukrajiny [Publicprivate partnership as a modern mechanism for attracting investments in the infrastructure of Ukraine]. (PhD Thesis). Kyiv: ScientificResearch Institute of Economics

2 Bondar N.M. (2014) Rozvytok transportnoji infrastruktury Ukrajiny na zasadakh derzhavno-pryvatnogho partnerstva: monoghrafija [Development of transport infrastructure of Ukraine on the basis of public-private partnership: monograph]. K.: NTU. (in Ukrainian)

3 Varnavskiy V.G., Klimenko A.V., Korolev V.A. (2010) Gosudarstvennochastnoe partnerstvo: teoriya $i$ praktika
[Public-Private Partnership: Theory and Practice]. M.: SU-HSE. (in Russian)

4 Vdovenko Ju.S. (2009) Pryvatnoderzhavne partnerstvo $v$ avtodorozhnij sferi: monoghrafija [Private-government partnership in the road sector: a monograph]. Chernihiv: ChTTU. (in Ukrainian)

5 Volokhov V.A., Markova I.V. (2010) Obgruntuvannja vprovadzhennja mekhanizmu derzhavno-pryvatnogho partnerstva na zaliznychnomu transporti [Justification for the implementation of the mechanism of public-private partnership in rail transport]. The bulletin of Transport and Industry Economics. No 32, pp. 25-28

6 Zapatrina I. V. (2010) Publichnopryvatne partnerstvo v Ukrajini: perspektyvy zastosuvannja dlja realizaciji infrastrukturnykh proektiv i nadannja publichnykh poslugh [Public-Private Partnership in Ukraine: Perspectives for Implementation of Infrastructure Projects and Public Services Provision]. Economics and Forecasting. No 4, pp. 62-86.

7 Danjko M.I., Dykan V.L., Voloveljsjka I.V. (2013) Vybir optymaljnoji innovacijnoji strateghiji pidpryjemstv zaliznychnogho transportu: monoghrafija [The choice of the optimal innovation strategy for rail transport enterprises: a monograph]. Kharkiv: Ukrainian State Academy of Railway Transport

8 Pashhenko Ju.Je., Korinj M.V. (2015) Derzhavno-pryvatne partnerstvo jak mekhanizm finansovogho zabezpechennja rozvytku transportnoji infrastruktury zaliznycj [Public-private partnership as a mechanism of financial support for the development of transport infrastructure of railways]. The bulletin of Transport and Industry Economics. No 49, pp. 74-79.

9 Tokmakova I.V., Daraghan O.O. (2013) Sutnistj ta pidkhody do formuvannja investycijnoji strateghiji na pidpryjemstvakh zaliznychnogho transportu [Essence and approaches to the formation of an investment strategy in railway transport enterprises]. The bulletin of Transport and Industry Economics. No. 43, pp. 189-193. 
10 Pro

derzhavno-pryvatne partnerstvo: Zakon Ukrajiny vid 1 lypnja 2010 roku \# 2404-VI [On public-private partnership: Law of Ukraine dated July 1, 2010 No. 2404VI]. Available

at: http://zakon2.rada.gov.ua/laws/show/2404-17.

11 Realizacija proektiv derzhavnopryvatnogho partnerstva $v$ Ukrajini: praktychnyj posibnyk [Realization of PublicPrivate Partnership Projects in Ukraine: A Practical Guide]. Available at: https://mtu.gov.ua/files/Посібник\%20Реаліза ція\%20ДПП\%20в\%20Україні.pdf.

12 Dovidka shhodo rezuljtativ zdijsnennja DPP (1 pivrichchja 2018 rik) [Reference on the results of the PPP (1st half of 2018)]. Available at:
http://www.me.gov.ua/Documents/Print?lang= uk-UA\&id=62a9b6fb-27ff-462a-b351-

eeeadfb26b6f

13 Morozova N.I. (2013) Rol' gosudarstvenno-chastnogo partnerstva $\mathrm{V}$ formirovanii i realizatsii sotsial'no orientirovannoy politiki Rossii [The role of public-private partnership in the formation and implementation of socially oriented Russian policy]. European perspectives. No. 6, pp. 512.

14 Gosudarstvenno-chastnoe partnerstvo: ucheb. posobie dlya bakalavriata $\mathrm{i}$ magistratury (2016) [Public-private partnership: studies. manual for undergraduate and graduate]. M.: Publishing Yurayt. (in Ukrainian)

\title{
БЕЗПЕКА ГОТЕЛЬНИХ КОМПЛЕКСІВ ЯК СКЛАДОВА ЕФЕКТИВНОСТІ ТУРИСТИЧНОГО МЕНЕДЖМЕНТУ ТА ПРИВАБЛИВОСТІ ТУРИСТИЧНИХ ПІДПРИЕМСТВ ДЛЯ ВІТЧИЗНЯНИХ ТУРИСТІВ (НА ПРИКЛАДІ ТУРЕЧЧИНИ)
}

\author{
Козлова А.О. к.е.н., ст. викладач (ХНУМГ імені О.М. Бекетова)
}

В статті обтрунтовано необхідність забезпечення життєво важливих інтересів туриста (особи) під час перебування в краӥні відпочинку, а саме безпеки перебування в готелі. Встановлено, щэо важливу роль у забезпеченні безпеки туристів відіграє менеджмент готельних комплексів та туристичних операторів. Констатовано, щзо не тільки менеджмент туристичної галузі повинен опікуватися розв'язанням ичих питань, а й органи влади і управління держави, правоохоронці, як провідники начіональних інтересів, в тому числі економіки країни. Зроблено висновок про намагання державних інституціий окремих держав покращчтти стан безпеки перебування туристів в країні за рахунок втілення сучасних технологій $і$ стандартів. Запропоновані нові, нестандартні форми і підходи щэодо поліпшення стану безпеки туристичного середовища.

Ключові слова: туризм, туристичні потоки, готелі, менеджмент муристичної галузі, безпека туристів, безпека готелів, охорона готелів, якість послуг. 